\title{
A Study Management in Logistic System Service Idea of Retailers in Bangkok
}

\author{
Sudarat Pimonratanakan \\ College of Logistics and Supply Chain, Suansunandha Rajabhat University, Thailand
}

Copyright $\bigcirc 2016$ by authors, all rights reserved. Authors agree that this article remains permanently open access under the terms of the Creative Commons Attribution License 4.0 International License

\begin{abstract}
The objectives of this research were to study of the idea of retailer about service, study about idea levels of retailer of logistic service and study of problems in other services included commendation and recommendation about the solving problem and improving in term of logistic service. This research was a survey research. The sample group in this research was retailers that collected data by distribution questionnaire for 400 samplings then to data analysis by percentage, mean, standard deviation t-test and f-test. The research result found that most of respondents were women for 200 persons, age around 30-40 years, married status, bachelor's degree and retail experience above 5-10 years, the idea about logistic service in term of quantity of products which had corrective order, time of delivery to fast, convenience, value added product service and communication with purchasing department that total had average at high level respectively. The hypothesis testing found that personal factors were gender, age, status, education levels and retail experience difference. The idea of quality of logistic service of retailer was not different statistical significance level of 0.05 therefore retail learnt about the key of logistic service principles.
\end{abstract}

Keywords Service, Retailer, Logistics

\section{Introduction}

Service of business for other units in term of responding to customer and retailer demand and ability to communicate and responding between those units such as logistic management unit managed service level of retailer that it assisted organization to know about the ability to keep current customers and how much attractive the new customers onward, competency, efficient service became customer loyalty and value added for the business as well. Logistic shown performance result of service such as the place was the part of marketing section that was the performance of service which could be measured the logistic unit about the utilities in term of time and place where was emphasized retailer. Level of logistic service that the business served units for instance marketing or production unit which was impacted the competency of organization about responding the customer and retailer demand, ability to communicate and responding between those units. Logistic unit on the service level to retailer would assist to know the current customers wanted and how much attractive new customers in the future.

Retailer market nowadays had competition more because there was new entry entrepreneur to compete market share both of big and small entrepreneur focused on price strategy set lower by competitor. Distribution to other provinces that the old entrepreneur mentioned promotion extensively caused the customer loyalty in product.[5]

Overview in retail business in 2014 found that the quantity of trading volume decline from last year, it was reflected GDP in retail sector arrowed growth rate $0.6 \%$ only (at the same price) decelerated when compared with 2013 growth $3.2 \%$ related to direction of economic expansion in 2014 growth $0.7 \%$. However, driving force of modern trade still had the supporting factor like amount of branches covered all areas in country and presented customer behavior turn to buy the products through modern trade more as a result overall business to be able expanding on positive side among purchasing power of customer not be bright. [13] 


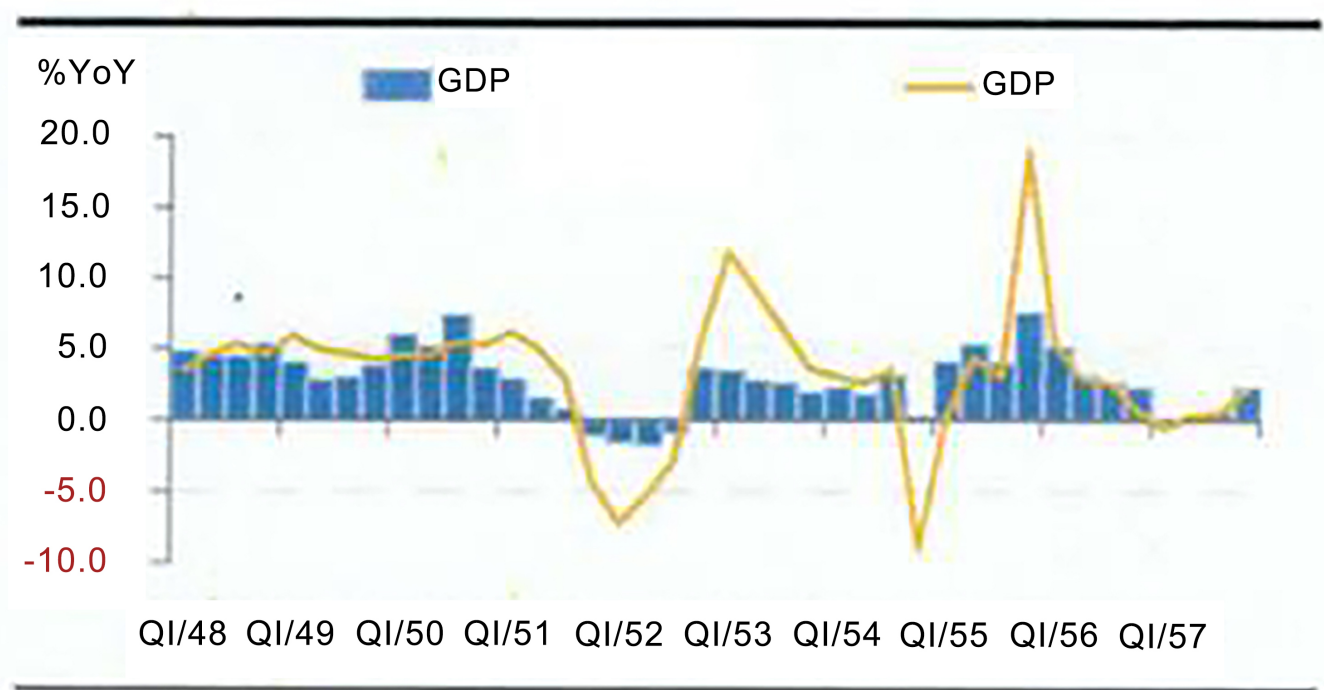

Figure 1. Growth rate of GDP and GDP of retail sector

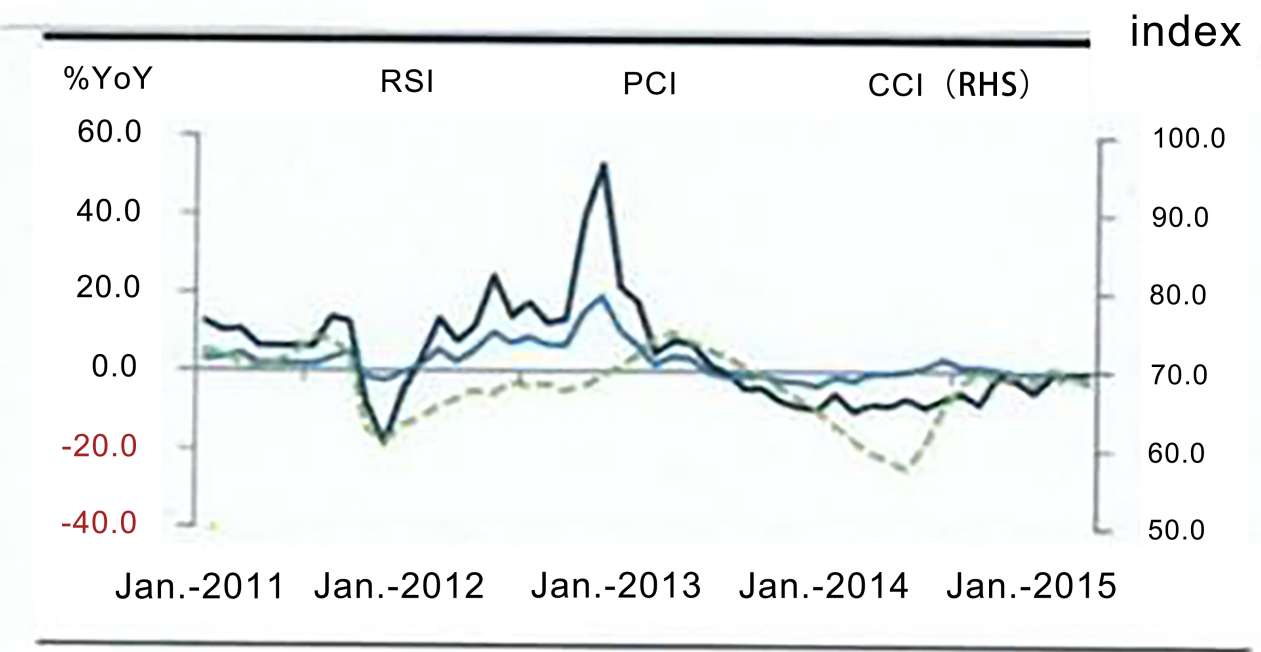

Figure 2. Growth rate of Retail Sale Index (RSI) and Private Consumption Index (PCI)

The consideration about the trade quantity indicator in the beginning of year 2015 found that it had shrink and reflected the retail sales index at the level 205.3 declined in the same month of last year at $0.4 \%$ continuity from 2014 shrink to $6.1 \%$ particular declined in the part of vehicle still shrink $5.6 \%$ continuously in the same period in last year due to some customer rushed buying the vehicle under the first car of government policy in previous year accordance with private consumption index and customer confidence index down in the first two month in 2015.

Growing trend of retail business in 2015, it was expected retail business arrow growth. Thai Economic expected growth $2 \%-3 \%$ because the pressure of export sector still down continuous from last year additional investment and government expending delay included the private expending till shrink caused the limited revenue declined of agricultural sector but the cost of living and household debt level were still high; beside, there were not any supporting factors which assisted to increase revenue or purchasing power of customer in nearby the reason was that the economic recovery was delayed in spite of expecting the modern trade growth would be significant booting and helping market growth due to the fact that it met good the current customer's demand and cover all areas further the booting of promote economic growth on second round of government that could disburse in second quarter of year. The oil price was still low level as well as the tourism sector grew in the good level, it could stimulate by private spending to certain extent. [3]

The factors that contributed growth of business expansion in urban areas and expansion prosperity to other regions all of this were the contributed factors to more invest in retail in term of normal inflation rate was low level in oil price situation had decline as well, it was the good affection to consumption and investment of private sector through Asian Economics Community in 2015 in addition the growth of border trade, expanding branches continuity, market 
strategies and increase distribution channel as online sale, those would stimulate customer spending at a certain level. Factors had negative affected the growth of business and political stabilization in country that affected the confidence and atmosphere of customer spending included the confidence to invest of retailer in world economic situation still light recovery; moreover, it affected Thai export and purchasing power of customer indirectly which was pressured to problem of the living cost and household debt were high level, lower price agricultural products, limited areas to expand branches, problem of suitable area was declined and stick of legal requirement was not only Building Control Act but also Land Planning Act etc. Retail business expected arrow growth trend according to Thailand's economic expected to expand; retailer would aware the service to customer signification, however. The important of retail business operation was customer because the customer satisfaction was successful of business; hence, retailers focused on the logistic service and solve the logistic problem to meet each of customer satisfaction. Currently, business was high quality of logistic service, it had scope of integrated service that focused on service and created satisfaction by cost arrangement efficiency to responding customer's demand and delivering satisfaction to their customers.

Even though the business was aware of the importance of service, it still faced poor quality of service. Many businesses referred to the fortuity service that getting the officer who was cheerful or love to service specially when came to work or released service improvement appearance after complained by customers till unable to get beyond.
Poor service had no direction and lack of good planning become worse of business and difficult to keep customers who had many choices to choose unlimited. Currently, if we intended to create the service for customer impression, we could keep the customers in the long run as this result researcher studied this title from barrier about the quality of logistic of retailers who were not ready for logistic management that was the executive had to improve quality of logistic more to create the competitive advantage and value added of business.

Research objectives

1. To study concept of service quality of retailer

2. To study about the idea of retailer about the logistic service

3. To study about the services problem and suggestion the guideline of logistic improvement in service quality

\section{Hypothesis}

Personal data factor were gender, age, status, education level and any different position had the idea about quality of any logistic service.

\section{Delimitation of Research}

Population in this study was 400 retailers in Bangkok.

\section{Conceptual Framework}

Researcher to study management in logistic system service idea of retailers in Bangkok had the conceptual framework to study as the detail in picture 1 .

\begin{tabular}{|c|c|}
\hline $\begin{array}{l}\text { Personal data factors } \\
\text { - Gender } \\
\text { - Age } \\
\text { - Status } \\
\text { - Education level } \\
\text { - } \quad \text { Retail business } \\
\text { experience }\end{array}$ & $\begin{array}{l}\text { Logistic service of retailer in } \\
\text { Bangkok } \\
\text { - } \text { Time delivery management } \\
\text { - } \text { Credibility } \\
\text { - } \text { Communicating with } \\
\quad \text { purchasing department } \\
\text { - Convenience } \\
\text { - Product quantity order } \\
\text { correctly }\end{array}$ \\
\hline
\end{tabular}

Figure 3. Conceptual Framework 
Independence variable consisted by personal data factors gender, age, education level and retail business experience Dependence variable consisted by studying logistic system service idea of retailers in Bangkok in term of time delivery management, credibility, communicating with purchasing department, convenience, and product quality order correctly.

\section{Expected Benefits}

1. Research result were made awareness of retailer feature to service quality in Bangkok

2. Research result were made awareness of solving and improvement gotten by the idea of retailer in Bangkok

3. Research result were made awareness of suggestion and idea or retailer in Bangkok

\section{Contents}

In this research, researcher studied research of a study management in logistic system service idea of retailers in Bangkok had the research theory related as follow.

\subsection{Theory and Idea about the Logistic Management}

When considered the meaning of logistic management on Webster's dictionary found that logistic management was science of the part of military related to supply, maintain forces, moving, uploading, welfare for officer and any convenience and in term of meaning of management in business of The Council of Logistics Management or CLP where was the professional organization of logistic in United State said that logistic management means the part of supply chain system that had the planning process. [6]

History of logistic from the beginning to present that it has developed divided by the period as follow; [2]

In 1950-1964 started to develop logistic system in military activity, it was the era of producing product mainly, logistic management was person acting on its own included warehouse department and transportation cost in distribute products process was high at the end of century 1964 started the coordination in distribution product process but lack of the person responsibility for warehouse and selection the activity in logistic

In 1965-1979 was accessing through logistic system as development of material management related to distribution product that customer wanted the higher service caused to find the marketing strategy, finding the alternative in term of cost and revenue analysis and starting to see both of quantity and quality service became the purchasing process involved. This era started to consider the profit, cost reduction, communication from executive level according to return of investment (ROI) mentioned the asset investment and management more

In 1980-1990 was economic recession era when stated the impacted on investment, lack of capital due to error handling distribution management and material management of company, started to expansion business to across countries more, energy was scarcely and uncertainly, logistic management had to use the energy to move, stated the systems union, officer had serious negotiation, joint venture was important because managements in term of marketing, production and distribution were adapted to logistic, those reasons were all organizations tried to find guideline using all factors involved in distribution and manufacturing additional distributor and customer so that purchasing level was supplied to be optimal with customer's demand by reduction of inventory, the round of purchasing, each period of processing and logistic cost in all systems whereas the problems occur in this era were nobody seen the picture of customers demand further inventory level clearly. Driven by competitive market affected each party had decision to be alliance business and joint venture more.

In 1990 to present is the information technology which was taken it to interchange information between organizations such as there was taking electronic data interchange system, it was the interchange data from several parties together through electronic media caused to reduce error of import data, reduce complication job affected the flow of information technology faster, reduce the time of each activity. As a result of working through internet, the decision of administration is faster in addition to increase core competency of competitive advantage in world economic system more.

The key of logistic management efficiency and effectiveness caused the competitive advantage beyond business competitors not only in term of quality, lower cost difference, on time speed of service and the important thing was the goods and services were cheaper in order to create the satisfaction and loyalty of customer for making decision to buy production in the future and created more flexible within organization.

Efficiency of logistic management had importance for company in 2 guidelines were increase revenue in term of sale and reduction of cost production and services, cost from management both of storage and flow of product by selection between activities in logistic system for instance between inventory quantity and transportation. If company wanted to have low inventory, it had to transport several times. Cost consideration would be decided by selection lower activity cost and not affected customers and the company could select any method. Efficient logistic management means the selection logistic activity that total cost reduction using in company resources could be best implementation; furthermore, there was planning and suitable management or effective cost management or reduced expenses so operation could be shorten the period shorter effected the customer satisfaction owning to meet their satisfaction said that logistic affected goods and service in term of quantity, quality, time, place and price correctly; thus, logistic could create royalty in products and looking good image of company caused to increase revenue from sale more eventually. [2]

The important thing of logistic management was the part of inventory in order to increase core competency of competitiveness by maintain existing customer and adding 
more new customer, it was cos reduction, product good quality, not damage or loss during transport or deliver that fast and on time so service for customer when they wanted the products and getting satisfaction then they would come to repeat purchase in short when it took logistic management implement should consider others side were;

1. Inventory management policy was important to enterprise which was practice to hit the objective or target that executive specified direction correctly accordance with the principles and vision of organization.

2. Specified location of manufactory or company had to consider the relation with production process, location of material used in production process, market place, regulation of plant and readiness of utilities system, those were effected the product cost directly and overall efficiency of operation in logistic system of manufactory.

3. Executive had to plan the operation since material, production and transportation planning or warehouse till going to customer.

4. Transportation plan during production and plant layout necessity to parallel operation and had to the principles in operation according to the guideline of logistic management that focused on management about time and location to transport in production process.

Moving and storing products had to have the efficiency and effectiveness in logistic management which had complexity affected wide scope and related with several departments in organization and outside organization more in each department had different target as a result it complicated and lack of quality in supply chain management. Logistic had activities, those activities were interaction addition one logistic effected the other activities operation and cost. [4]

Logistic management and supply chain were the key concepts to assist promotion import and export spreading to country-wide and global efficiency further convenience and fast. Executive necessary had to adjust the operation process by improving knowledge, learning process, spreading knowledge and getting utilization from knowledge in both theory and practical. Research and development caused getting new knowledge which was the benefit to take it to develop in operation system affected the development of industrial manufacturing sector were growth included economic of country development as well.

Logistic had total 13 activities which were the main activities of organization divided into 2 parts: one were 8 activities mainly another 5 activities were operation supporting of organization the following details; [12]

1. Customer service was activity that organization tried to respond customer's demand this will be a good one Based on the performance of logistics activities into other aspects attributed specifically to deliver the goods on time and in full amount.

2. Order process was activity that it tried to respond customer's demand faster. Currently the organization to most computer systems. And managing business-oriented electronic help. For easy and fast.
3. Forecasting demand was prediction demand of product or customer service in the future that were the important activities to create the profit or loss of operation. Anticipating customer needs in advance. It allows companies to set direction for the operation that will produce or how many resources available. And much if the forecast customer demand crash. It will affect the cost and performance of the company. The fact that none of its clients or, in contrast, may have too much inventory.

4. Inventory management was the important another activity because existing inventory quantity effecting the one way or not particular capital which organization had high inventory, it could respond to customer's demand high too but at the same quantity of goods. The organization also took the opportunity cost of funds into circulation. Cost of storage. Therefore, organizations must take into account the level of inventory that can meet the needs of their clients. In order to reduce costs.

5. Transportation covered all activities which were moving product from beginning to customize most effective delivery must be fulfilled in perfect condition. And given the time it's said that in view of the common man. Transport activity Logistics with the most obvious.

6. Warehousing and storage was activity related with warehouse management such as storage, area management in warehouse, equipment necessary for operation in warehouse. Currently warehouse management activity was able to create the value added products and another way as well.

7. Reverse logistic was whether was damaged or expired products and so forth or not

8. Purchasing was activity related with purchasing, supply and service all of selections raw material supplier, specified period, order quantity and creating relationship with raw material supplier

9. Part and service support was responsible for after sale-service which was the part of the service of company to customer. e.g.: The supply of spare parts and equipment; To prepare for the quick service. If the product was defective, responsibility of aftermarket products is to satisfy the customers and powerful clients. This results in the long run to purchase in the future. There was a good feeling with the brand. So it can be said that this event has helped the company to maintain long-term relationships with clients save.

10. Plant and warehouse site selection was the selection factory and warehouse location where had to focus on distance between raw material and customer closely for ease of access And involves a range of transport, including the ability to meet the needs of customers.

11. Material handling was the activity related with material moving and in process inventory included moving finished goods with in factory or warehouse. The purpose of the management of raw materials during production is to decrease the distance of moving as much as possible to reduce the number of revision procedures as a bottleneck to flow better. Reducing transport as much as possible to save on labor costs. To achieve these objectives, Organizations 
want to reduce the number of moving objects as possible because each time they are moved. There will be costs incurred from moving. There will be costs incurred from moving raw materials. So if you can reduce the value in this field. It will contribute to the cost of production per unit decreased.

12. Packaging in that marketing, it was shown the external feature of product which could attract customer interested in product but the package logistic was dominated different from marketing. The first package is in place to protect the product is not damaged while being moved, secondly, good packaging will help the process moving and storage more convenient.

13. Logistic communication was efficient communication in organization which was another key factor effecting the organization successful and any decision able to do fast and more efficiency also efficient communication of organization. The communication in logistic was effective communication the following had best do;

- Having communication between supplier and customer

- Having communication between organization particular accounting department, marketing and production department

- Having communication between logistic all 13 activities

- Having communication between units for example sale department and customer service in marketing department

- Having communication between member in supply chain system which hadn't contact with organization directly such as the earliest suppliers in supply chain

Mainly activity of logistic in all 13 activities might be grouped into 5 groups were activities of production management, marketing and customer service, supplying various material and equipment, warehouse management and delivery included the knowledge of logistic. This study the researcher would study only the supporting activities related to packing particularly

Logistics consists of six major parts.

1) Managing logistics management system as part of the supply chain is a logistics management system within the organization, while supply chain management is to manage the relationship between the organizations.

2) The essence of logistics management is the "system" has to be planned to follow the implementation of activities planned. And most importantly, the system must be able to control a variety of factors. Other relevant

3) Management of logistics needs to move goods, services and information, efficiency and effectiveness, which would result in an organization to control and reduce costs as they occur.

4.) The movement of goods, services and information systems to flow to and when to sell. There must be a system that can support the product was sent back for repair or destruction, and thus make the process flow system is completely gone.

5) The scope of managed logistics. This internal management organization starting from the beginning of the organization, such as the procurement of raw materials and supplies to end the activities of organizations such as the distribution and so on.

6) The most important aspect of management services, logistics is to be able to meet the needs of their clients. Therefore, the management of logistics that must achieve two things together is able to meet the needs of their clients and the ability to control costs in the system.

\subsection{Theory and Concept of Reducing Time of Delivery Product}

Working method improvement or reducing procedures of work in order to reduce period of transportation, it was the part increasing more working effective to assist transportation process. The specialists gave the meaning and focused on reducing period or procedures in transportation as follow;

Working method improvement or reduce working process in order to reduce transporting time that was the part of increasing working efficiency and assisting increased efficient transportation process operation as well. [8]

Studying working method in any process was development working new method that easy, convenience, fast, and low cost. Those method had higher efficiency than former method, less working process too also the target was higher productivity, reduce loss, and lower cost. In 1911 Frank Bunker Gillbreth specified the meaning of motion study meaning was working analysis technique to eliminate motion that was necessary and allocated the best working method and fastest in working further standard improvement or procedures of equipment and training employees to work in the correct method. Wording of method and mobility study had the same meaning and target to increase effective in production process too then definition of "method" replaced "mobility" that was the objective of studying how to work as follow; [12]

1. To improve new production process more effective

2. To develop new working to be convenience, easy and reduce fatigue

3. To increase effective by production factors more for example human, money, material, machine, energy technology, land, building, management and necessities that were necessary for production products and services

4. To improve location and work environment optimization with behavior of organization

5. To specify transportation method of material onto new production higher effective

6 . To specify standard of method

\subsection{Theory and Concept about Retailer}

Trainee in organization proposed factors for assessment to be retailer as follow; [14] 
Factor applied to assessment of being retailer as follower;

1. Ability of innovation

2. Ability the deal with the mess

3. Wishes to success

4. Ability the plan realistically

5. To be leader focusing on target

6. Retailer collecting data and truth included study and specified possible guideline

7. Having responsibility

8. Adaptability

9. To be organizer and administrator

Entrepreneur means business pioneer by its own who had implementation plan and operated in all parts by own also accepted the risk occurred all the time to mention profit from performance of their business. [11]

Entrepreneur was the person who seen the business opportunity, finding the way to build their business and ready to take risk that occurred from decision to start business in small and medium enterprise need entrepreneur who had more competences could aspect the entrepreneur behaviors as follow;

1. Creative to start business was who see the opportunity and the way to build business under many environments

2. Learning or create innovation of business operation caused the new product and service included production process, marketing and resource allocation etc.

3. Accept risk might occur from the performance of loss or failure so entrepreneur necessary was risky as principles that was instant decision and carefully with reliable information

4. Having capable in general management both specified direction of business and resource allocation

5. Focus on performance intention to create growth and profit from performance

\section{Qualifies of entrepreneur}

Successful of small and medium enterprise had to refer the owner or entrepreneur who had better suite qualifies for entrepreneur under uncertainly whole time explained the qualification of new millionaire who was achievement had 7 properties as follow;

1. To be finding opportunity person was who see the opportunity and finding commerce channel whole time; thus, it was under economic crisis.

2. To be risk and brave ready to manage promptly when see the opportunity, do not wait otherwise it is to late not get anything.

3. The person with initiative or creative of new production product and service throughout market in high competitive.

4. The person who does not give up easily and is patient particularly at the beginning of foundation business faced many problems so the millionaire or entrepreneur could persist to has to be high patient person.

5. The person who always want to know causes the creative and alert whole time effected adaptable always too.

6. The person who had wide vision affected direction of business obviously and run on rail business could emphasize to the future by target specified absolutely.

7. There had to have good network caused getting both data and assistances from friends or good network.

\subsection{Theory and Concept of Service Quality}

Services were vision of organization to create customer satisfaction this was the activity that officer in organization had to mention and tried to training about service mind, quality of corporate business management in all types development so the service competitive strategy to increase productivity progression, that had to have target to create customer satisfaction. [9]

The service mean holding activity to respond demand widely divided by 2 kinds were;

1. Organizations that meet public service mean safety such as Royal Thai Police, Office of the Customer Protection and so forth.

2. Organizations that meet public utilities such as electricity, water supply and Telephone Organization of Thailand .

Service concept was assistance or operation for the benefit of other people had to hold the practical principle, it was not the assistance or making the benefit to other people were followed our pleasure whose service. Generally, service principle should consider as follow;

1. Consistently, to meet customer's demand in term of service had to focus on customer mainly and taking their demand to specified the service providing. Even though, it was the assistance that we saw that it's good and suitable for customer, customer who was not interested in that service become worthless.

2. Affecting customer satisfaction, quality was satisfaction of customer in basically; therefore, service had to focus on customer satisfaction and it was the main to assess service performance that intended providing service any more but it was only quantity while quality of service could be measure by satisfaction of customer.

3. Practical in correctly, perfect, and service responding to meet customer satisfaction clearly, it could see clear that practical had to verify accuracy and completeness. If there was error, it was difficult to make customer satisfaction; even if, there was the wording like sorry or apologized, it receives only mercy.

4. There was not injury to other person in any service feature had to consider carefully and focused on benefit to the customer and us only. It was not enough to take various parties concerned included social and environment further they should adhere service principles carefully and should not cause impacted damage to other parties.

Service means the action or performance that entrepreneur gave consumer was intangible. Customer bough products and service had not the right to be owner of any property beside the right of service had deal with only. The opinion of the good service principles as follow; 
1. Provided service accordance with the good service principle of the most people

2. Provided service hold to one's principle always

3. Provided service hold to one's principle equality

4. Provided service hold to one's principle of saving

5. Provided service hold to one's principle of convenience

Royal Institution Dictionary B.E gave the meaning word "service" mean [10]

"servant practice and giving the conveniences" in the general meaning often mention that completed fill to help or operate the benefit to other parties, the wording met the English as "Service" this word we was familiar and most person required the service for own satisfaction. Service was the operation that practice or contact to customer that giving to persons gotten any benefit with any effort by several method caused other related person to get help that was the service such as facilitate, responding satisfaction to customer and several service method to operate. The main point was help and facilitate to customer.

\section{Service in public sector}

Service public sector concerned the benefit to population that was the public service further there was objectives the well- being of the public but it not intended for compensation in higher revenue than expenses or profit therefore service in public sector was most the free of charge feature. If there was a fee for service, it looked as compensation cover the expenses in existing services. In several types of service, government had to accept loss performance for public in whole getting the benefit from public service. Public service had both direct and indirect service; direct service such as civil registration, cleanliness and public health, indirect service for example keeping the peace, public order, prevention and mitigation public hazard, town and country planning, public utilities and infrastructure. The public service had to improve related to social environment and facilitate to public as much as possible. The public service in government sector had some error occurred impacted negative image of unit but it not affected people much in spite of organization could exist so service development in government sector depended on leadership of unit was important.

\section{Service in private sector}

Service in private sector concerned profit to get not only directly but indirect in term of running business of private stood on the fundamental of survival and prosperity therefore service had to have costs and expenses these were considered together with payback listing. If service had not the payback, it could not operate because it had not power to call the tax from citizens to be expenditure budget as a result private revenue came from sale products and service but the service had to appropriate compensation, not to take advantage from citizen. Service in private sector, if it had some error, it impacted the survival of organization accordingly executive would serious pay attention caused they was responsible for themselves and own status obviously for service in private sector had clear auditing system.

\section{Research Methodology}

Collected data would be analyzed and stored in both primary and secondary data which were designed by questionnaire collecting from retailer such as primary data was from interview retailer and secondary data was the collected responding reqeustionnaire from retailer. Collected data method was the questionnaire which was the collected data tool and processing in statistic of percentage, average, standard deviation T-test and F-test.

\section{Target group and sample size}

This research had the objectives to study about logistic service idea of retailer in Bangkok and it was survey research as studying of population group of administrative district in Bangkok [1].

Step 1 Selecting location area how to cast by not return back in each group of administrative district for each group as 1 area that got survey area to be representative such as Rattanakosin group in Rajathewe district, Burapa group in Bang khen district, Srinakarin gruoup in Nong Chok district, Chaopaya group in Bang na district, South of Kongton group in Thon Buri district and North of Kongton in Bangkok Yai district.

Step 2 Using quota sampling was representative as quota for survey in each area the amount of sample group for 400 persons who were Rajathevee district for 66 persons, Bang khen for 66 persons, Nong Chok district for 67 persons, Bang Na district for 67 persons, Thon Buri district for 67 persons and Bangkok Yai district for 67 persons. [15]

Step 3 Convenience sampling till full amount of size sampling group for 400 persons.

\section{Research instrument}

Research instrument and record data were questionnaire. Researcher asked the suggestion from specialist, professor and advisor to check accuracy from specialist's tool for 5 persons who was special as research and research tool testing to find reliability and population nearby sample group of 30 persons taking questionnaire and finding reliability by alpha-coefficient of Cronbach getting coefficient reliability of questionnaire $=0.89$.

Questionnaire that researcher would create to collect data from sample group divided by 3 parts such as first part was data of retailer personally as respondent for instance gender, age, status, education level and retail business experience had feature like questionnaire and check list second part was the questionnaire like the idea and concept about the logistic service of retailer consisted for 5 parts were time of delivery to fast, reliability, communication with logistic department, convenience, and quantity of purchasing order correctly and third part was idea and recommendation of respondent who were retailer that was open-ended questionnaire using the 
assessment principle of Likert Scale separated for 5 levels as;

Score 5 points mean opinion at highest level

Score 4 points mean opinion at high level

Score 3 points mean opinion at middle level

Score 2 points mean opinion at less level

Score 1 point means opinion at least level

\section{Scores result translation}

Researcher specified the translation meaning of average value from opinion to arrange the level of average value by period as below

4.50-5.00 means retailer had opinion at highest level

3.50-4.49 means retailer had opinion at high level

2.50-3.49 means retailer had opinion at middle level

1.50-2.49 means retailer had opinion at less level

1.00-1.49 means retailer had opinion at least level

\section{Collection data}

Researcher collected data by tools as questionnaire from retailers who were asked by retail business unit replied the questionnaire independent to answer and researcher needed questionnaire back immediate then researcher took time to collect data around 3 months

\section{Research Result}

To propose this research study of logistic service idea of retailer in Bangkok consisted research result proposal and data analysis result as follow;

\subsection{Personal Factors of Respondent}

Respondent such s retailer found that 220 women for 55 percent and 180 men for 45 percent, lower 30-40 years for 150 persons at 37.50 percent and $41-50$ years for 120 persons of 30 percent then lower 30 years for 95 persons of 23.75 percent and over 51 years for 35 person of 8.75 percent, marriage status was marriage for 315 persons of 78.75 percent, widow for 55 persons of 13.75 percent, high school and lower for 100 persons of 25 percent and retail business experience over 5-10 years for 350 persons of 87.5 percent and lower 5 years for 50 persons of 12.50 percent.

Table 1. The amount and percentage of personal data of retailer

\begin{tabular}{lll}
\hline \multicolumn{1}{c}{ Classification } & Amount (people) & Percentage (\%) \\
\hline Gender & 180 & \\
Man & 220 & 45.00 \\
Woman & & 55.00 \\
\hline Age & 95 & \\
$\quad<30$ years & 150 & 23.75 \\
30-40 years & 120 & 37.50 \\
41-50 years & 35 & 30.00 \\
$\quad>$ 51 years & & 8.75 \\
\hline Marriage Status & 30 & \\
$\quad$ Single & 315 & 7.50 \\
Marriage & 55 & 78.75 \\
Widow & & 13.75 \\
\hline Education Level & 100 & \\
High School or lower & 300 & 25.00 \\
Becherlor's degree & & 75.00 \\
\hline Retail business experience & 50 & 12.50 \\
$\quad$ < 5 year & 350 & 87.50 \\
\hline 5-10 years &
\end{tabular}


Table 2. Average, standard deviation and idea level of retailer about quality of logistic service

\begin{tabular}{llll}
\hline Quality of logistic service & $\overline{\mathrm{x}}$ & S.D & Opinion level \\
\hline 1. Time of delivery to fast & & & Agree \\
2. Reliability & 3.75 & 0.51 & Agree \\
3. Communication with logistic department & 3.80 & 0.40 & Agree \\
4. Convenience & 3.54 & 0.61 & Agree \\
5. Quantity of purchasing order correctly & 4.07 & 0.55 & Agree \\
6. Value added product service & 3.45 & 0.93 & Agree \\
\hline \multicolumn{1}{c}{ Total } & $\mathbf{3 . 6 7}$ & $\mathbf{0 . 6 1}$ & Agree \\
\hline
\end{tabular}

Table 3. Comparison average of retailer idea to quality of logistic service classified by gender, age, status, education level, and retail business experience

\begin{tabular}{|c|c|c|c|c|}
\hline$\underline{\text { Classification }}$ & $\overline{\mathrm{x}}$ & S.D & $\mathbf{t}$ & Sig. \\
\hline \multicolumn{5}{|l|}{ Gender } \\
\hline Man & 3.66 & 0.39 & .032 & .974 \\
\hline Woman & 3.66 & 0.34 & & \\
\hline \multicolumn{5}{|l|}{$\begin{array}{l}\text { Marriage Status } \\
\text {. }\end{array}$} \\
\hline Single & 3.60 & 0.32 & 1.93 & .056 \\
\hline Marriage & 3.76 & 0.41 & & \\
\hline Widow & 0 & & & \\
\hline \multicolumn{5}{|l|}{ Educatin Level } \\
\hline High School/Lower & 3.61 & 0.36 & 1.718 & .090 \\
\hline \multicolumn{5}{|c|}{$\begin{array}{c}\text { Diploma/High Vocational Certificate. } \\
0\end{array}$} \\
\hline Becherlor's degree & 3.75 & 0.35 & & \\
\hline Higher Becherlor's degree & 0 & & & \\
\hline \multicolumn{5}{|l|}{ Experience } \\
\hline$<5$ years & 0 & & & \\
\hline $5-10$ years & 0 & & & \\
\hline $10-15$ years & 0 & & & \\
\hline $15-20$ years & 3.66 & 0.36 & 0.513 & 0.609 \\
\hline$>20$ years & 3.85 & & & \\
\hline
\end{tabular}

\subsection{Data Analysis Result Related to the Idea of Retailer to Logistic Service}

Retailer had idea in all parts of logistic service for 6 parts by retailer as agree ( $\bar{x}=3.67$ ) priority by score average from most to less were quantity of purchasing order correctly $(\bar{x}=4.07)$, reliability $(\bar{x}=3.80)$, Time of delivery to fast ( $\bar{x}$ $=3.75)$, convenience $(\bar{x}=3.54)$, value added product service $(\overline{\mathrm{x}}=3.45)$ and communication with logistic department ( $\overline{\mathrm{x}}=3.41)$ respectively.

\subsection{Hypothesis Test Result}

Comparison average value of idea of retailer about the quality of logistic service classified by gender, status, education level and experience by statistic t-test found that classification by gender of retailers had the idea about quality of logistic service overview in man gender found that had the idea for 3.66 and women for 3.66 and when test the different of average value between sample group by t-test found that $t$ was .032 and sig total at .974 shown that man and women had idea about the logistic activity of customer service in overview were not different in statistical significance for 0.5 mean that retailers were men and women had idea about quality of logistic service not different

Classification by status of retailers had idea to quality of logistic service in overall, they were single and marriage had idea for 3.60 and 3.76 respectively and when test the different of average value between sample group by t-test found that $t$ was 1.93 and sig at 0.56 shown that single and marriage had the idea about the quality of logistic service were not different in statistical significance level at 0.05 mean retailers were different status but the idea about the quality of logistic service not different.

Classification by education level of retailer had the idea about the quality of logistic service in high school and lower found that they had idea for 3.61 and Bachelor's degree had the idea for 3.75 and when test the quality service of logistic management in overall were not different in statistical significance level at 0.05 another respondent had only two groups so this was replied by t-test mean retailer had education level do not difference and the idea about the quality of logistic service not different too. 
Table 4. Variable analysis to compare with the difference of average value about the idea of retailer to the quality of logistic service classified by age in overview

\begin{tabular}{|c|c|c|c|c|c|}
\hline Variable & Df & SS & MS & $\mathbf{F}$ & sig. \\
\hline$<30$ years & 3 & .048 & .016 & .118 & .950 \\
\hline $30-40$ years & 0 & & & & \\
\hline 41 - years & 0 & & & & \\
\hline$>51$ years & 76 & 10.320 & .136 & & \\
\hline Total & 79 & 10.900 & & & \\
\hline
\end{tabular}

Classification by retail business experience had the idea about the quality of logistic service found that they were 15-20 years had idea for 3.66 and over 20 years had idea 3.85 and when test the different of average vale between sample group by t-test found that $t$ was 0.513 and sig was 0.609 shown that retailers had service quality had the idea about the quality of logistic service in overall were not different in statistical signification level at 0.05 mean retailer had different business experience and had the idea about the quality of logistic service not different.

Classified by age of retailers, there were different ideas about quality of logistic service. Overview was not different statistical significance level at 0.05 mean that retailers were age different but their ideas about quality of logistic service were not different.

\section{Conclusions}

In this research study found that the most respondent were women who were 30-40 years their marriage status, education in Bachelors' and retail business experience over 5-10 years.

Research result found; moreover, that retailer had the idea all parts of quality of logistic service at 6 parts were retailer had the idea the most agree $(\bar{x}=3.67)$ priority by score average from most to less were quantity of purchasing order correctly $(\bar{x}=4.07)$, reliability ( $\bar{x}=3.80)$, Time of delivery to fast $(\bar{x}=3.75)$, convenience ( $\bar{x}=3.54$ ), value added product service $(\overline{\mathrm{x}}=3.45)$ and communication with logistic department $(\bar{x}=3.41)$ respectively.

Research result found; beside, that personal factors were gender, age, marriage status, education level and different business retail experience had the idea about quality of logistic service of retailers were not different in statistical significance level at 0.05 caused by retailer had learn to focus on the logistic service knowledge of business logistics raise the standards of quality management, business logistics. It supports the creation of knowledge, business development services, logistics services and quality standards related to providing logistics to the following standards.

\section{Discussion}

From research result found that ability to take to discuss about the research result followed by the hypothesis in this research as follow.

1. Personal factors affected the idea of entrepreneur to quality of logistic service not different in all factors in statistical significance level at 0.05 . Research result is in accordance with the research result of Parinya Buatong to study of expectation of customer to quality of Chicken Treat at Future Park Branch. This research found that the customer who had different personal factors had expect to factor of service quality not different in statistical significance.

2. Research result found that the idea in each idea was not different to logistic activity of customer service that had idea about the average from highest to lowest were reliability, time, convenience, and value added of service and less level for instance communication. Research result accordance with Kietipong Nakprapa to study of "Expectation of customer and acknowledge of quality of service of Dtac service office (Service all)' case study of Dtac service in Bangkok area and accordance with the service principles focused on 5 components were relation with demand of most people, consistency, equality, saving and convenience, responsiveness, competence, courtesy, creditability, access and communication.

\section{Suggestion}

From research result had some recommendation that saw the important issues about service had to study and distinguish who you were serving and what you should know any knowledge to study and the following elements;

1. Feeling was the feature of feeling or personal emotion and positive feeling such as liking, satisfaction and compassion and negative feeling for example dislike, unsatisfied, and hate.

2. Thinking was the brain of human to acknowledge and decide any data received became to knowledge, idea or situation caused the attitude between right or wrong and good or bad.

3. Behavior was the readiness to act or respond to the source of attitude so officers and companies were aware of service satisfaction additional hold the training of service such as listen to customer wanting, what the customer need 
and how and so on caused the customer known about us mean to give the customer service information of the company the most for example any technology what had any equipment and readiness of officer to service and so forth.

4. To study research other variables in company more in order to increase the research result to apply in development and increase efficiency of business management of company.

5. To study compared to the idea of officer in company in any part between other companies.

6. To monitor the result of research improvement and development logistic systems as the demand of retailer efficiency next.

\section{Acknowledgements}

The author would like to thank the Research and Development Institute, Suan Sunandha Rajabhat University, Bangkok, Thailand for financial support. The author also would like to thank Professor Komson Sommanawat, Director of Institute of Lifelong Learning this research paper.

\section{REFERENCES}

[1] Administration districts that registration announcement with municipal highway of Highways Act B.E, 1992.

[2] Apipruchyakul, Kumnai. Logistic and supply chain management, strategy for cost reduction and increasing profit, Bangkok; Focus Media Publishing Company Limite, 2007.

[3] Bank of Thailand and Center of Economics and Business Forecasting of University of Thai Chamber of Commerce, 2015.
[4] Chaimankong, Chaiyote \& Chaimankong, Mayukapan. Logistics and Supply Chain Strategy for Competition in World Market. Bangkok: CY System Printing, 2007.

[5] Kasikorn Thai Research Center. Retailer in Thailand in B.E,1, 2015

[6] Daniel, P., \& Olhager, J. "Supply chain integration and performance: The effects of long-term relationships, information technology and sharing, and logistics integration." International Journal of Production Economics 135(1), 514-522, 2015.

[7] Fawcett, S. E., Ellram, L. M., \& Ogden, J. A. Supply chain management: from vision to implementation. London: Pearson, 2014.

[8] Jandasang, Duangjai. Factors Affecting the service of Transportation use outbound freight Case study of Operators. Ph.D in Social Science journal, 5(3), 52-67. 2015.

[9] Thongrawd, Chairit. The realization of integrated marking communications that affect Purchasing behaviors of adolescent girl cosmetics in Bangkok. Journal of Management Science, 1(1), 111-125, 2015.

[10] Royal Institution Dictionary B.E,1999.

[11] Simachockdi,Vitoon. SMES: Pillar of nation industrial recovery. Bangkok: Technology Promotion Association (Thailand-Japan), 2008.

[12] Sutthachaidee, Wannee. The Logistics Management of Coconut-Shell Products: A Case Study of Samut Songkram Province, Thailand. Suan Sunandha Rajabhat University, 2015.

[13] The Office of Business Research of Land and House Bank Public Company Limited. 2015.

[14] Tianputh, Danai. To be entrepreneur, Business Journal, 2009.

[15] Zikmund, W. G. Exploring Marketing Research. 7th ed. New York : The Dryden, 2000. 